\title{
The Implications of the Shift towards Standard Financial Reporting Specialist for Small and Medium-Sized Companies to Attract Foreign Investment in the Iraqi Environment
}

\author{
Sadeq Musdeq Hassan ALasdy¹, Baker Ibrahim Mahmoud ${ }^{2}$ \\ ${ }^{1}$ Accounting Department, Mustansiriya University, Baghdad, Iraq \\ ${ }^{2}$ Accounting Department, University of Al Mustansiriya, Baghdad, Iraq \\ Email: suhagas122@gmail.com
}

How to cite this paper: ALasdy, S.M.H. and Mahmoud, B.I. (2019) The Implications of the Shift towards Standard Financial Reporting Specialist for Small and MediumSized Companies to Attract Foreign Investment in the Iraqi Environment. Open Access Library Journal, 6: e5205.

https://doi.org/10.4236/oalib.1105205

Received: January 24, 2019

Accepted: February 24, 2019

Published: February 27, 2019

Copyright $\odot 2019$ by author(s) and Open Access Library Inc.

This work is licensed under the Creative Commons Attribution International License (CC BY 4.0).

http://creativecommons.org/licenses/by/4.0/

\begin{abstract}
Small and medium-sized entites (SMEs) are the main backbone of the economy of any country, whether developed or developing, where these companies are characterized by their high capacity to provide jobs, and are the main drivers of further technological innovations and are therefore considered one of the main engines of the growth of the economy. Given the importance of the role played by small and medium-sized entites (SMEs), the International Accounting Standards Board (IASB) issued an international standard for small and medium-sized entites (SMEs) in 2009 and an amendment was made in 2015, instead of the full set of comprehensive international Financial Reporting Standards (IFRS) that Designed for companies that trade their financial markets, and in the light of Iraq's approach to adopting international accounting standards, especially since 2016 has been implemented by Iraqi banks with the aim of this research to determine the applicability of the international Financial Reporting standard for medium-sized companies And small in the Iraqi environment and what are the consequences if it is applied to the Iraqi economy, especially in attracting foreign investment. The research has reached a number of conclusions, the most important of which are: 1) the transition to the financial reporting standard for small and medium-sized entitles (SMEs) in the Iraqi environment remains incomplete in terms of the appropriate political environment and the legal and legislative environment that initiates this transformation as well as the economic and regulatory environment; 2 ) the common accounting system applied in small and medium-sized entites (SMEs) has become highly criticized due to its obsolescence, although it has been amended in 2011 but does not conform to the requirements of international standards. The main recommendations of
\end{abstract}


the research are: 1) the need to undertake radical reforms at various political, legal, economic and regulatory levels with a view to creating the appropriate environment required by the process of transition towards the financial reporting standard for small and medium-sized entites; 2 ) the professional and regulatory bodies of the accountancy and auditing profession in Iraq (the Financial Supervisory Board, the Association of Accountants and Auditors, the Board of Accounting and Supervisory Standards, the Auditing and Audit Profession Council) should exercise their real role and be the leader in the process of transformation.

\section{Subject Area}

Environmental Sciences

\section{Keywords}

Foreign Investment, Financial Reporting, IFRS FOR SMES, SMES, IFRS

\section{Introduction}

Small and medium-sized enterprises (SMEs) are the main pillars of any economy as they represent the largest proportion of companies operating in any country, whether developing or advanced. They are also characterized by other companies as companies that do not need large capital, and they help to provide a lot of employment opportunities, reduce the problem of unemployment, and contribute to the diversification of sources of income for members of the community, which leads many countries of the world to take care of this sector in terms of aspects administrative and accounting.

In view of the importance of the role played by SMEs, the IASB issued an international standard for SMEs in July 2009 and amended in 2015, rather than the full set of international reporting standards. IFRS has been designed for companies that trade their securities in the financial markets, and hence these standards are extensive and complex, especially in the field of measurement and disclosure, so these publications to ease the burden on small and medium-sized enterprises, and after the economic developments in Iraq and the openness of the international markets and integration with the international economy must be directed towards the implementation of this standard for small and medium enterprises, as the Iraqi banks began in 2016 to apply international accounting standards, which contributes to attracting foreign investment and reflects in turn on the development of the Iraqi economy. The country is moving towards building, reconstruction and opening up to world markets.

\section{Methodology}

\subsection{Study Problem}

The accounting treatment currently applied in the Iraqi environment does not 
discriminate between large, medium and small companies, as all companies of all types apply the common accounting system and the Iraqi accounting rules, so this is a pressure on medium and small companies to be responsive to the same large corporate requirements. With the trend towards adopting international accounting standards, its international standard must be applied, so the problem of research is that the current treatment does not give privacy to these companies, how is it if the international standard is applied? What are the repercussions of the application on the Iraqi economy especially in attracting foreign investments, the research problem can be summed up by trying to answer the following questions:

- Can the international financial reporting standard for small and medium-sized enterprises be adapted to the requirements of the Iraqi environment?

- What are the impediments to the application of the international Financial Reporting standard for small and medium-sized enterprises in the Iraqi environment?

- What are the implications of the application of the international Financial Reporting standard for small and medium-sized enterprises (SMEs) in attracting foreign investment?

\subsection{Research Objectives}

Seek to achieve the following objectives:

1) Theoretical framing of the nature, specificity and importance of small and medium-sized enterprises.

2) Identification of the contents of the international financial reporting standard for small and medium-sized enterprises.

3) To know the applicability of the international Financial Reporting standard for small medium-sized enterprises (SMEs) in the Iraqi environment.

4) To identify the obstacles that may face the mechanism of applying the standard in the Iraqi environment.

5) To identify the implications of the application of the financial reporting standard for small and medium-sized enterprises in attracting foreign investment within Iraq and its impact on the development of the Iraqi economy.

\subsection{The Importance of Research}

is illustrated by the importance of research through the role of small and medium-sized enterprises in the economy of any country, whether developed or developing, where these companies are characterized by their high capacity to provide job opportunities, as it is a way to stimulate self-employment and private work as well as it needs a low cost Relative to the initiation of activity in it is also the main motivation for more technological innovations and export diversification and is therefore considered one of the main engines of the growth of the economy. Therefore, highlighting the international accounting processes for the activities of these companies and disclosing the results of their actions in an in- 
ternationally acceptable manner will be reflected in the development of the economy by attracting foreign investment, creating jobs, eliminating unemployment, investing capital, obtaining funding sources and activating Economic movement in general and that our country is in dire need of it.

\subsection{The Research Hypothesis}

It is based on the thesis of the president: the adoption of the international financial reporting standard for small and medium-sized enterprises (SMEs) influences the attraction of foreign investment.

\subsection{Sample Research}

A sample was selected who have knowledge and experience in the field of accounting and economics where 45 people were selected as a sample of research distributed as follows:

1) (20) University professor who holds the title of Professor or assistant professor in the Departments of Accounting and economics at various Iraqi universities.

2) (25) First-class and certified auditors to work according to the Bulletin of the Auditing and Audit profession board for 2018.

\subsection{Methods of Data Collection}

1) On the theoretical side of the research, all available books, research, letters, and messages, which have been presented in relation to the subject of research as well as websites in the Internet, especially the websites of international accounting organizations and other international organizations, have been relied upon to obtain the latest information.

2) On the practical side, a questionnaire was prepared and distributed to the selected sample personnel. The questionnaire included two main axes: the first: The focus was on identifying the availability of the transition to international accounting standards for small and medium-sized enterprises in the Iraqi environment. This axis has been divided into four factors, as follows:

The first factor: the political environment-the second factor: the legal and legislative environment-the third factor: the economic environment-the fourth factor: the regulatory environment.

The second axis:

To identify the implications of the shift towards the financial reporting standard for small and medium-sized enterprises (SMEs) on the development of the Iraqi economy, particularly in attracting foreign investment.

\section{The Theoretical Aspect of Research}

\subsection{The Definition of SMEs and Nature of Small and Medium Enterprises}

There is no universally agreed definition of small and medium-sized enterprises, 
and there is no single definition that can be understood in relation to all dimensions of small and medium-sized enterprises, nor can one be expected to reflect differences between firms, sectors or countries at different levels development (Mirza and Holt) [1], where a study by the State Institute of Georgia indicated that there are more than 55 definitions of small and medium enterprises in 75 countries and small and medium enterprises are defined based on a set of criteria including the number of workers, the size of capital or a mixture of The standards together the islands of (Jazer and Ruwaiha) [2].

The World Bank, for example, defines small and medium-sized enterprises (SMEs) by using the standard number of workers, which is a principle criterion and is considered a small company if it employs less than 50 workers and many countries in the world use this standard to define small and medium-sized companies in the United States America, Italy and France consider the company to be small and medium if they employ up to 500 workers and in Sweden up to 200 workers and in Canada and Australia 99 workers while in Denmark employs up to 50 workers and this standard is good for ease of comparison process and gather information about it while other countries depend on Capital size for the definition of a small and medium-sized company, which makes it difficult to compare these countries to the difference in currency exchange rates (Tamimi and Halim) [3].

As for Iraq, the Central Statistical Organization has identified two basic criteria for distinguishing between small companies and other companies (Al-Khuzaie) [4].

1) The number of workers in the project between 1 and 9 workers.

2) The value of the machines and equipment used in the project shall not exceed (100,000 IQ).

\subsection{The Importance of Small and Medium-Sized Enterprises}

Is the importance of small and medium-sized enterprises in the role they play in the process of economic growth at various stages, as they not only contribute to the increase of production significantly, but achieve social goals and contribute to attract foreign currency reserves to a country in addition That it contributes to job creation which means that it is the backbone of the private sector all over the world (Ensari and Karabay) [5]. This there are several facts that call for the need to focus on supporting, supporting and raising the efficiency of small and medium-sized enterprises in developing countries, as follows (Al-Asrj) [6].

1) Micro, Small and medium enterprises (SMEs) are the dominant pattern of companies in the Arab countries, accounting for $99 \%$ of the total non-agricultural private economic institutions in Egypt, contributing about $80 \%$ of the combined value added by the private sector and employing about two-thirds of the workforce and three Quarters of employees in private jobs outside the agricultural sector in Kuwait, this sector accounts for approximately $90 \%$ of the private enterprises operating, and includes one employment, estimated at $45 \%$ of the labor force and national employment by less than $1 \%$ and in Lebanon these institu- 
tions constitute more than $95 \%$ of the total institutions and contribute about $90 \%$ of jobs in the UAE, small and medium-sized enterprises (SMEs) have formed about $94.3 \%$ of the country's economic projects and employ about $62 \%$ of the labor force by about $75 \%$ of the total country's GDP.

2) These companies provide jobs for a broad base of the Arab labor force, estimated at about one third of the workforce or more.

3) These companies participate in the addition to the national economy where this contribution was estimated at $96 \%$ of GDP in Yemen in 2005 and about 77\%, 59\%, 25\% in Algeria, Palestine, Saudi Arabia respectively during the same year, while the contribution of these companies varies between $25 \%-40 \%$ of GDP Egyptian gross domestic.

4) These small companies are effective mechanisms for the production and provision of low-cost and affordable goods and services, especially for the sectors of citizens with limited incomes.

5) These small firms represent a successful means of mobilizing and re injecting small savings into investments.

6) These companies represent the main pillar through which the private sector operates in the Arab States, and their support is therefore supportive of the role of the private sector in economic activity.

7) Attracting foreign investment a report by the organization praised the leading role of small and medium-sized enterprises (SMEs) in field-based resolution and the study of specific cases following the Asian financial crisis in seven Asian countries, to the possibility of these institutions raising the Asian region's share of foreign investment Direct to more than $15 \%$ and can attract a small amount of foreign investment and enter into joint projects with foreign partners, which may contribute to the transfer and localization of modern technology, expand the production base, improve the quality of the product and enhance the ability of the manufacturing capacity especially in the emerging productive sectors in the country.

\subsection{What Are the International Financial Reporting Standards International}

Accounting standards are the standards that were issued between 1973 and 2001, when the International Accounting Standards Committee (IAS) assumed responsibility for the development of these standards (41) and in 2001 the International Accounting Standards Committee (IASC) was replaced by a board International Accounting (IASB) he became the standard-setting officer based in London-UK and is an independent body composed of members from nine different countries around the world with a variety of functional backgrounds and during the first meeting of the Board, he accredited IAS and continued to The development of new standards has become known as International Financial Reporting Standards (IFRS), where the International Financial Reporting Standards (IFRS) replaced the previous IAS and the naming of many international Financial Reporting Standards (IFRS) has been established under the same name 
as previous International accounting standards (Kumar) [7]. These standards are used by publicly accountable companies, which are listed in financial markets such as stock exchanges and financial institutions such as banks, the number of international Financial Reporting Standards (IFRS) up to 2017/12/31 (17) is standard, and explanations are developed and prepared Supported to provide additional guidance on how standards are applied by the international Financial Reporting Standards (IFRIC) Interpretations Committee, the Board also developed the international Financial Reporting standard for non-publicly accountable small and medium-sized enterprises (SMEs), which was first registered in the year 2009 (http://WWW.IFRS.ORG) [8]. The said standards are universally recognized for the preparation of financial statements and reports as the International Financial Reporting Standards (IFRS) determine what comes (Pacter) [9].

1) Items to be recognized as assets, obligations or undertakings.

2) How to measure these items.

3) How to provide it in the form of a full set of financial statements.

4) Relevant disclosures on those items.

\subsection{The Historical Development of the International Financial Reporting Standard for SMEs}

The formal practices of the International Accounting Standards Board (IASB) began with the subject of financial reporting for small and medium-sized enterprises (SMEs) starting in 1998 when the International Accounting Standards Board (IASC) introduced SME project. The committee held several discussions but the scope of the project was not specific In the immediate [2] aftermath of the establishment of the IASB in 2001, the IASB appointed a working group of experts to study the project, with the objective of preparing an international accounting standard that takes into account the specificity of SMEs as well as countries developing countries (Azzawi and Amal) [10]. The first document, referring to standards for small and medium enterprises, was published in June 2004 in the discussion paper "Preliminary Opinions on the Accounting Standards for SMEs (Pascu and Vasiliu) [11]. Receiving comments on the initial discussion paper, it turned out that many are demanding simplification of accounting recognition and accounting policies, but very few gave the alternative, nor was there any reference to issues that should be modified in the new standard, which led to the need to provide more information to assess what issues You need to simplify and modify it The Board held open public meetings in April 2005 with SME financial report preparers and users (Azzawi and Amal) [10]. Based on this project, field tests were conducted by the IASB on a sample of 116 small companies from 20 countries. Based on the comments and reviews on the draft (Amier and Farooq) [12], it was published publicly in February 2007 in four English, French, German and Spanish languages, and from March 2008 to April 2009, 13 open public meetings were held This period is for revision of the draft standard presentation before Finalize it. In July 2009, the standard was issued 
in its final form, and a three-year period was set each time to revise the standard according to the developments.

It is clear from the above that the draft of the international standard for small and medium-sized enterprises has gone through several stages. The project started from the basic idea that came as a result of the IASC study of the needs of SMEs in terms of financial reporting rules and their need to produce reliable financial reports High quality in order to enable investors, lenders and external users to access the financial statements of these companies, which in turn helps to meet their different needs on the one hand, and on the other hand, these companies play an important role in the global economy if it constitutes approximately $95 \%$ of the total number of companies around the world. This standard is used to regulate these companies in accounting terms. This standard is a revised version of the International Financial Reporting Standards (IFRS). Approximately 90\% of the measurement and disclosure requirements have been reduced in the preparation of the financial statements.

\subsection{The Objectives of the IFRS for SMEs}

The full IFRS is designed to meet the needs of investors in equity companies, which cover a wide range of issues and contain a large amount of implementation guidance, including disclosure of appropriate information for large companies. However, users of financial statements of SMEs do not have the same needs but are more focused on assessing short-term cash flows. Many small and medium-sized enterprises believe that full IFRSs impose a burden on them, which grew after reporting standards International Finance is more detailed and more countries have begun to use it.

Thus, the idea of developing the proposed standards for small and medium-sized enterprises came into play. The IASB worked to reconcile the needs of users with the balance between costs and benefits. The objective of the project was to develop standards tailored to the needs of institutions that were not publicly accountable and to publish financial statements for general purposes to external users. This IFRS is based on full IFRSs with appropriate adjustments based on the needs of users of financial statements from SMEs and cost and benefit considerations (Yunus and Fawzi) [13].

It is clear from the above that there are multiple objectives for the issuance of the IFRS for small and medium-sized companies, including the need for this type of companies to a framework that results in useful information of high quality, in addition to the absence of this standard makes small and medium enterprises resort to comply with international standards Which is a burden on them in terms of the cost of the obligation. Therefore, the main objective of the Standard is to establish principles and bases of measurement and recognition that are simplified and appropriate for the needs of such companies. This standard consists of 35 parts each is interested in a particular subject in terms of recognition, measurement and disclosure. 


\subsection{Obstacles to the Application of the Financial Reporting Standard for Small and Medium-Sized Enterprises}

There are several constraints to the application of IAS in SMEs. Some companies may be exposed to some of these constraints (Judges) [14] and (Siam) [15]:

1) Lack of sufficient knowledge in accounting and administrative matters and inability to plan the project and forecast future cash flows and the lack of guarantees required to obtain funding and the inability to obtain long-term financing for the purchase of machinery and equipment.

2) The weakness of the accounting and financial culture among the owners of small and medium sized companies, the lack of desire to organize accounting matters, the lack of accountability for management, and the non-separation of ownership from management.

3) Weak capacity, expertise and human resources necessary and limited financial resources and national and foreign investment necessary to develop them.

4) The difference of laws and legislations between countries and the disparities in the role of professional bodies and associations entrusted with supervising the profession of accounting and the different economic and social conditions and the differences in concepts and behaviors and values prevailing and cultural differences between societies.

\subsection{The Concept and Nature of Foreign Investment}

Before talking about the concept of foreign investment should first be addressed to the concept of investment in terms of language, and economic it is linguistically the use of the word investment to denote the "request to obtain the fruit and seek to obtain it, and use it " (Micah) [16] in economic terms, investment has been defined as "the use of savings in the formation of new productive capacities for the production of goods and services and the maintenance or renovation of existing production capacity" (Al Shammari) [17] and under the Investment law Iraqi No. (13) of 2006 the investment was defined as the hiring of money in any economic activity or project that is of legitimate benefit to the country (Iraqi Investment Law) [18] and it is noted from previous definitions that the term investment in general is to abandon funds at a given time in order to obtain a return through These funds are spent on developing new means of production or developing old ones. When dealing with the concept of foreign investment, it seems clear from the outset that every investment outside the national boundaries of the investor is a foreign investment of the country in which the investor is invested, and the source of such investment may be a foreign State, group of States, company, group of Companies or individuals (Gary) [19], either. The second term is foreign, and it refers to all that is non-national. The laws classify that, although it is a resident investment and in a host country, it is foreign ownership and belongs to a foreign individual or a foreign non-national company, so it is foreign investment and its types and deadlines vary depending on the type of foreign investment (Majid) [20].

Foreign investment, which is a type of investment that has sparked contro- 
versy and interest, is due to its multiple sources, forms and effects in its host countries. Foreign investment has been defined as: "It involves the export of capital from a particular country called the source country or the mother to another country called the importing or host country as investment is made in specific projects and sectors" (Mahdi) [21].

\subsection{Forms of Foreign Investment}

Most economic sources classify foreign investments into two main forms, direct and indirect investments, and we will address each of these in a concise manner, as follows:

\subsubsection{Foreign Direct Investment}

Foreign direct investment (FDI) means those investments owned and managed by the foreign investor, either because of their full ownership or ownership of a share, to the right of management. Foreign investment is characterized by a dual nature, the first being the existence of an economic activity by the foreign investor in the host country and the second of its total or partial ownership, that is, it takes the form of establishing foreign enterprises within other countries as a long-term investment, and the United Nations Trade and Development Report defines investment As an investment involving a long-term relationship that reflects the benefit of a foreign investor who may be an individual, a corporation or an enterprise, who has the right to manage his or her assets from his or her country of residence. (Alfloki) [22]. The International Monetary Fund (IMF) believes that foreign investment is direct when the foreign investor $(10 \%)$ or more than the ordinary shares or the voting power of the shareholders of a limited institution or equivalent for an individual institution (Majid) [20].

\subsubsection{Indirect Foreign Investment}

Is the indirect foreign investment method of the oldest forms of known global investments? The method at the beginning of the idea that the factory or product knows nothing about foreign markets, outside the borders of his state, especially before the development of modern transport, and that he has a surplus of production wants to dispose of it, sell it in foreign markets, and that these products need maintenance and after sales services and this increases The expenses and burdens of the product were the idea of the agency, and the following forms and images of commercial dealing such as distribution, trade representation, etc., and from this standpoint began the idea of indirect foreign investments (Gary) [19]. This type of investment is usually made by financing institutions (such as banks, and investment funds (or institutional investors (Institutional Investors) (e.g., pension funds, insurance companies) or by individuals (Majid) [20]. The foregoing defines indirect foreign investment as "Owning an external resident of shares and bonds in the host country to benefit from differences Fixed prices and interest earned by bonds often provide capital by participating in the shares of companies in the host country and without interfering mostly in the direct 
management of the company "(Mahdi) [21] from here we conclude that indirect foreign investment is in the form of capital provided by the fruit of the foreigner to the destination to be invested was to buy shares or bonds for a particular company without having the right to administer or control it.

\subsection{Impact of the Application of International Financial Reporting Standard for Small and Medium-Sized Enterprises and Their Impact on Attracting Foreign Investment}

Since small and medium-sized enterprises constitute a large proportion of the size of economic projects in most economies of the world and, consequently, their significant contribution to national income from the total size of the gross domestic product. These companies have the largest share in the economies of countries, which has brought their accounting systems to the attention of the authors of international accounting standards and their financial reporting according to international accounting requirements.

Developments in international trade and investment, the history of financial reporting, and both the auditing and accounting professions are also important challenges, the accelerating development of the business environment, the recovery of financial markets after the end of the Second World War, the emergence of ideas of globalization and the exchange of investment between State borders This also required the improvement of the financial reporting mechanisms, so that the applications of IAS and the full and streamlined IFRS in their current form were finally activated in order to make the financial statements comparable and universally accepted, with clear and uniform foundations.

The entry of foreign investments into the financial markets is evidence that there are signs and attractions that have led to the receipt of these investments linked to the desired return, safety and confidence resulting from the achievement of market readiness under the supervision of the Securities and organization authority through standards, rules and instructions. It has produced credibility, transparency, appropriate and reliable information and provides levels of disclosure, which are the most important factors attracting foreign investor.

\section{Analysis and Discussion of Respondents' Responses}

In this section, we will analyze and discuss the responses of the sample members on the questionnaires:

The first axis: Availability of the components of the transition to IFRS for small and medium enterprises in the Iraqi environment:

In order to determine the availability of the components of the transition to IFRS for small and medium enterprises in the Iraqi environment, the views of the selected sample were polled and their responses were as follows:

1) The political environment: The responses of the respondents on the questions related to the availability of the appropriate political environment as shown in Table 1. 
It is clear from the previous table that the responses of most of the respondents were in favor of the third question, where they supported almost $100 \%$ that the unstable security situation affects the efficiency of applying the IFRS for SMEs. As for the answers to the first and second questions, $67 \%$ believe that the prevailing political system does not support the trend towards applying the international financial reporting standard for SMEs, and 56\% of respondents do not believe that there is pressure from governmental and non-governmental organizations Yet. It should be noted that the political environment is not geared towards the application of IFRS for SMEs, and that supports the tendency of the respondents towards this is that the political factor is one of the factors affecting the accounting system, especially since the political system in Iraq is centralized, reflected in the use of the accounting system Unified control of all accounts of different sectors. Despite the claim of freedom from centralism, the political system still oscillates between centralization and decentralization of all its behavior. Although the trend towards international accounting standards in general, but the philosophy of this approach to international accounting standards is not derived from the thinking of the political system prevailing in Iraq, but came as a result of pressure from international organizations such as the World Bank and the International Monetary Fund, especially that Iraq in this period is suffering from a deficit In the budget, which resorted to borrowing from these organizations to fill the deficit, which made these organizations impose certain conditions appear to be one of the adoption of international accounting standards and we have not seen any direct government direct to the implementation of the IFRS for SMEs.

2) The legal and legislative environment: The respondents' answers to the questions related to the availability of the legal and legislative environment as shown in Table 2.

It is clear from the previous table that the answers to the first question were wavering between acceptance and rejection, while the majority (45\%) was toward moderation. As for the second question, most respondents (56\%) agreed that there is a conflict in some laws with regard to the mandatory application of the financial reporting standard international small and medium enterprises.

Table 1. Responses to questions related to the availability of the political environment.

\begin{tabular}{|c|c|c|c|c|c|c|c|}
\hline No. & Questions & Yes & Ratio & Some extent & Ratio & No & Ratio \\
\hline 1 & $\begin{array}{l}\text { Do you think that the prevailing political system supports the trend } \\
\text { towards the international accounting standard for SMEs }\end{array}$ & 5 & $11 \%$ & 10 & $22 \%$ & 30 & $67 \%$ \\
\hline 2 & $\begin{array}{l}\text { Are there pressures from governmental and non-governmental bodies } \\
\text { to adopt the International Accounting Standard for SMEs }\end{array}$ & 5 & $11 \%$ & 15 & $33 \%$ & 25 & $56 \%$ \\
\hline 3 & $\begin{array}{l}\text { The unstable security situation affects the efficiency of application of } \\
\text { the International Accounting Standard for SMEs }\end{array}$ & 35 & $22 \%$ & 10 & $78 \%$ & & \\
\hline
\end{tabular}


Table 2. Responses from responses to questions related to the availability of the legal and legislative environment.

\begin{tabular}{|c|c|c|c|c|c|c|c|}
\hline No. & Questions & Yes & Ratio & Some extent & Ratio & No & Ratio \\
\hline 1 & $\begin{array}{l}\text { Do the prevailing Iraqi laws require the application of the International Accounting } \\
\text { Standard for SMEs, especially the Companies Law and others }\end{array}$ & 10 & $22 \%$ & 25 & $45 \%$ & 15 & $33 \%$ \\
\hline 2 & $\begin{array}{l}\text { Do you think there is a conflict of some laws with regard to the mandatory application of } \\
\text { the International Accounting Standard for SMEs }\end{array}$ & 25 & $56 \%$ & 15 & $33 \%$ & 5 & $11 \%$ \\
\hline 3 & $\begin{array}{l}\text { he recent amendments to the consolidated accounting system in } 2011 \text { are consistent with } \\
\text { the application of the International Accounting Standard for SMEs }\end{array}$ & 10 & $22 \%$ & 10 & $22 \%$ & 25 & $56 \%$ \\
\hline 4 & $\begin{array}{l}\text { The consolidated accounting system is in line with the International Accounting } \\
\text { Standard for SMEs }\end{array}$ & 10 & $22 \%$ & 5 & $11 \%$ & 30 & $67 \%$ \\
\hline 5 & $\begin{array}{l}\text { he Iraqi accounting rules issued by the Accounting Standards Board are consistent with } \\
\text { the application of the International Accounting Standard for SMEs }\end{array}$ & 10 & $22 \%$ & 10 & $22 \%$ & 25 & $56 \%$ \\
\hline 6 & $\begin{array}{l}\text { Do you support the introduction of new legislation or amendments to existing laws and } \\
\text { regulations requiring the adoption of the International Accounting Standard for SMEs }\end{array}$ & 35 & $78 \%$ & 5 & $11 \%$ & 5 & $11 \%$ \\
\hline
\end{tabular}

As for the third question, most of the respondents agreed with $56 \%$ of the respondents, and this is not positive. This is the view that the recent amendments to the unified accounting system in 2011 do not correspond to the application of IFRS for SMEs. Of the respondents said that the current accounting system does not comply with the application of the IFRS for SMEs. This may be because the unified accounting system did not distinguish between large and medium and small companies, but it is applied in all companies without discrimination. But this does not mean that the entire system does not comply but there are certain items and paragraphs are somewhat compatible. As for the fifth question, $56 \%$ of the respondents agreed that the Iraqi accounting rules do not comply with the application of the IFRS for SMEs, while the remaining 44\% support the existence of the agreement in absolute or to some extent. This may be justified by the fact that the accounting rules issued by the Board of Accounting and Control Standards (14) are all old rules issued before 2003. No accounting rules have been issued. Therefore, they did not keep pace with developments in International Accounting Standards. There is no rule that refers to medium and small companies. As for the sixth question, $89 \%$ of the respondents supported in absolute terms or to a certain extent the issuance of new legislation or amendments to the prevailing laws and regulations required to adopt the procedures of applying the international financial reporting standard for SMEs. A clear and explicit legal provision for legal adoption is better than a reference in this or that law and subject to several interpretations and interpretations that may obscure the truth and lead to differences and thus the absence of a clear and unified view of adoption.

3) Economic Environment: The respondents' answers to the questions related to the availability of the economic environment as shown in Table 3.

It is clear from the previous table that the first question was fully supported $89 \%$ or to the extent that the nature of the current Iraqi economy is not conducive to the application of IFRS for SMEs. The trend of this sample may be justi- 
fied by the vagueness of the Iraqi economy. The nature and nature of the Iraqi economy is not clear. Before 2003, it was socialist-oriented and after 2003, it was based on the transition to a market economy, but only the advertiser and the practitioner are still socialist or perhaps a mixture of this. The second question $89 \%$ of the respondents agreed in absolute terms or to some extent that international economic pressures have an impact on the application of IFRS for SMEs. This may be justified by the pressures of international organizations to undertake, inter alia, the adoption of international accounting standards in order to obtain loans or credit facilities as well as WTO requirements to allow Iraq to join them.. The third and final question of this factor supported $89 \%$ in absolute or to some extent that Iraqi SMEs are unable to apply the IFRS for SMEs, while only $11 \%$ supported it. This may be justified by the fact that small and medium-sized companies have been using a unified accounting system for more than three decades and have been trained and trained by all. Consequently, the shift to the IFRS may be rejected from accounting practitioners because, by nature, people face change, Feel that this is part of their career legacy and therefore difficult to waive and replace the new as well as lack of experience and knowledge of the requirements of the international standard.

4) The regulatory environment: The respondents' answers to the questions related to the availability of the regulatory environment as shown in Table 4.

The previous table shows the weakness of the regulatory role of the regulators and supervisors of accounting and auditing practices in Iraq in exercising their

Table 3. Answers of sample members on questions related to the availability of the economic environment.

\begin{tabular}{|c|c|c|c|c|c|c|c|}
\hline No. & Questions & Yes & Ratio & Some extent & Ratio & No & Ratio \\
\hline 1 & $\begin{array}{l}\text { The nature of the current economy is encouraging for the application of the International } \\
\text { Accounting Standard for SMEs }\end{array}$ & 5 & $11 \%$ & 16 & $36 \%$ & 24 & $53 \%$ \\
\hline 2 & $\begin{array}{l}\text { Do you think that international economic pressures have an impact on the application of } \\
\text { the International Accounting Standard for SMEs }\end{array}$ & 25 & $56 \%$ & 15 & $33 \%$ & 5 & $11 \%$ \\
\hline
\end{tabular}

Table 4. Responses of respondents to questions related to the availability of the regulatory environment.

\begin{tabular}{|c|c|c|c|c|c|c|c|}
\hline No. & Questions & Yes & Ratio & Some extent & Ratio & No & Ratio \\
\hline 1 & $\begin{array}{l}\text { Is there a competent central authority to transfer the implementation of the IFRS for } \\
\text { SMEs }\end{array}$ & 10 & $22 \%$ & 10 & $22 \%$ & 25 & 56 \\
\hline 2 & The auditors are able to supervise and control the mechanisms of applying IFRS for SMEs & 25 & $56 \%$ & 5 & $11 \%$ & 15 & $33 \%$ \\
\hline 3 & $\begin{array}{l}\text { Here is a role for the Board of Accounting and Auditing Standards in the process of } \\
\text { transition to the implementation of IFRS for SMEs }\end{array}$ & 15 & $33 \%$ & 10 & $22 \%$ & 20 & $45 \%$ \\
\hline 4 & $\begin{array}{l}\text { The role of the Association of Accountants and Auditors is influential in the process of } \\
\text { transition to the application of the IFRS for SMEs }\end{array}$ & 5 & $11 \%$ & 15 & $33 \%$ & 25 & $56 \%$ \\
\hline 5 & $\begin{array}{l}\text { The Audit and Audit Board has a significant role to play in ensuring the transition to the } \\
\text { implementation of IFRS for SMEs }\end{array}$ & 15 & $33 \%$ & 10 & $22 \%$ & 20 & $45 \%$ \\
\hline
\end{tabular}


real role in the process of transition to the application of IFRS for SMEs. 56\% of respondents supported the absence of a competent central authority for the transition to the implementation of IFRS for SMEs, while the remaining $44 \%$ supported the existence of this entity. As for the second question, 67\% (or 67\%) agreed in absolute or to some extent that the auditors are unable to supervise and control the implementation of the implementation of the IFRS for SMEs. This may justify their belief that the auditors in Iraq are rooting for them to control the accounts prepared in accordance with the unified accounting system and have sufficient experience in this field and therefore if the application of the international standard will be an obstacle for them and need to understand the standard well to be audited. The third question related to the role of the Accounting and Control Standards Board of the Financial Control Bureau in the process of transition to the implementation of the IFRS for SMEs. The responses of the respondents ranged between acceptance and rejection. The supporters of this role were $55 \%$ absolute or somewhat those who reject this role $45 \%$. This fluctuation in the responses may justify that everyone expected a more positive role from the SAI in this regard, especially since the status and the prestige of the SAI require it to have a central role in this area, especially as it is the highest supervisory body in the country, his distinguished relations with the SAIs in different countries of the world. As for the fourth question, 56\% support that there is no effective role for the Association of Accountants and Auditors in the process of transition to the implementation of the IFRS for SMEs. While $44 \%$ believe the opposite. This fluctuation in the answers may also justify that the role of the union was not at the desired level and expected of it as the oldest professional organization in Iraq that hosts accountants and auditors, whose role is limited to holding seminars, workshops and conferences. The fifth question was that supporters of the role of the Council of the profession and audit control in the process of transition to the implementation of the IFRS for small and medium enterprises (55\%) in absolute or to some extent. While $45 \%$ say the opposite. This sample may also justify the fact that the Council of the profession was not at the required level to be assumed in this area, especially the regulator of the work of the auditors in Iraq, it must have a role in preparing the supervisory staff capable of dealing with the application of the reporting standard International financial institutions for SMEs.

The second axis: This axis focused on identifying the implications of the shift towards the standard of financial reporting for small and medium enterprises on the development of the Iraqi economy, especially in the field of attracting foreign investment.

To understand the implications of the shift towards the financial reporting standard for small and medium enterprises in the Iraqi environment on the development of the Iraqi economy, especially in the field of attracting foreign investments, the views of the selected sample were polled and their answers were as follows: 
It is clear from Table 5 that the majority of the respondents agreed on a number of possible repercussions in the Iraqi economy, especially in the field of attracting foreign investments if the transition to the financial reporting standard for small and medium enterprises in the first question (89\%) absolutely.

Or to some extent the adoption of the financial reporting standard for small and medium enterprises provides a fertile environment for attracting foreign investment. Their belief may be justified by the fact that most international companies, if not all, follow international accounting standards and thus direct their investments in the countries that apply those standards and away from countries that do not apply them to avoid problems and obstacles that may occur in terms of tax accounting, currency translation, etc., which may require two sets of data Financial one according to international accounting standards and others according to the standards of that country that does not apply standards and this holds the companies effort and time as well as unreliability of the numbers reached. As for the second question, the sample has agreed in absolute terms or to some extent that the adoption of the SME financial reporting standard contributes to the preparation of internationally comparable financial statements. This may justify their belief that the adoption of this standard would make the accounting output of the financial statements compatible with all countries. The data can be compared easily with the data of any other company in the country in which the standard was applied. This means that the financial statements have an international dimension. As to the third question, $78 \%$ support,

Table 5. Answers of sample members on questions related to the possible implications on the development of the Iraqi economy, especially in the field of attracting foreign investment.

\begin{tabular}{|c|c|c|c|c|c|c|c|}
\hline No. & Questions & Yes & Ratio & Some extent & Ratio & No & Ratio \\
\hline 1 & $\begin{array}{l}\text { Adoption of the financial reporting standard for small and medium enterprises provides } \\
\text { a fertile environment for foreign investment }\end{array}$ & 35 & $78 \%$ & 5 & $11 \%$ & 5 & $11 \%$ \\
\hline 2 & $\begin{array}{l}\text { The application of the SME Financial Reporting Standard contributes to the preparation } \\
\text { of internationally comparable financial statements }\end{array}$ & 35 & $56 \%$ & 10 & $22 \%$ & & \\
\hline 3 & $\begin{array}{l}\text { The foreign investor shall pay attention to the financial statements prepared in } \\
\text { accordance with the financial reporting standard for small and medium enterprises }\end{array}$ & 30 & $67 \%$ & 5 & $11 \%$ & 10 & $22 \%$ \\
\hline 4 & $\begin{array}{l}\text { The trend towards the financial reporting standard for small and medium enterprises } \\
\text { contributes to increase tax revenues }\end{array}$ & 20 & $45 \%$ & 10 & $22 \%$ & 15 & $33 \%$ \\
\hline 5 & $\begin{array}{l}\text { Adoption of the financial reporting standard for small and medium enterprises } \\
\text { contributes to the creation of new jobs through the expansion of companies and their } \\
\text { integration with the global economy }\end{array}$ & 20 & $45 \%$ & 10 & $22 \%$ & 15 & $33 \%$ \\
\hline 6 & $\begin{array}{l}\text { The shift to the financial reporting standard for small and medium-sized companies will } \\
\text { stimulate commercial activity in the Iraqi market as a result of the confidence of foreign } \\
\text { investors }\end{array}$ & 15 & $33 \%$ & 20 & $45 \%$ & 10 & $22 \%$ \\
\hline 7 & $\begin{array}{l}\text { The approach to the financial reporting standard for SMEs contributes to new sources of } \\
\text { funding by international financing organizations and banks }\end{array}$ & 25 & $56 \%$ & 15 & $33 \%$ & 5 & $11 \%$ \\
\hline 8 & $\begin{array}{l}\text { Adoption of the IFRS for small and medium enterprises contributes to the creation of } \\
\text { new investment projects and in various sectors }\end{array}$ & 20 & $45 \%$ & 10 & $22 \%$ & 15 & $33 \%$ \\
\hline
\end{tabular}


in absolute terms or to some extent, that the investor Foreigner pays attention to Financial statements prepared in accordance with the standard for small and medium companies financial reporting. This may justify their belief that the foreign investor always seeks to preserve his investments and therefore believes that the application of the international standard guarantees him internationally recognized financial statements. While $22 \%$ believe the opposite. The reason for their belief may be that the foreign investor is interested in making profits primarily regardless of whether or not the standard is applied. As for the fourth question, $67 \%$ of the respondents strongly supported, or to some extent, the approach to the financial reporting standard for small and medium enterprises contributes to increasing tax revenues. This may justify their belief that the SME reporting standard emphasizes the use of the fair value standard as well as the non-overstatement and adherence to caution and caution, which in turn increases the recognized revenues and thus increases the tax revenue. At the same time (33\%) say the opposite, and may be the reason they believe that companies have the maneuver and the capacity to avoid tax and minimize the amount of tax. As to the fifth question, $67 \%$ support, to a certain extent or to a certain extent, which the adoption of the financial reporting standard for small and medium enterprises contributes to the creation of new jobs through the expansion of companies and their integration with the global economy. This may justify the belief that the adoption of IFRS for small and medium enterprises contributes to the integration of Iraqi companies with the international economy and thus increase the movement of business transactions, making the financial position of these companies in a better position and thus have the ability to create new jobs. At the same time, $33 \%$ say the opposite. Believing that companies will seek to strengthen their financial position and enter into new investments without thinking about the interest of society and thus benefit only a small group of society. The sixth question supported (78\%) that the shift to the financial reporting standard for small and medium enterprises will stimulate the commercial movement in the market as a result of the confidence of foreign investors. This may justify the belief that the confidence of foreign investors in the Iraqi market is very weak at the moment and therefore if adopted by Iraqi companies.

This criterion may generate some kind of confidence in the foreign investor of these companies as they will be under the international umbrella. At the same time, $22 \%$ say the opposite. As for the seventh question, $89 \%$ agreed that the approach to the financial reporting standard for small and medium enterprises contributes to obtaining new sources of funding by international financing organizations and banks. This may justify their belief in the conditions set by these organizations for obtaining loans. The adoption of international accounting standards is one of the most important of these conditions. Therefore, SMEs will be able to obtain financing if they adopt this standard. As for the eighth question, $67 \%$ agreed that adopting the SME financial reporting standard contributes to the creation of new investment projects in different sectors. This belief may 
justify that if the adoption of the criterion will allow access to international funding as well as attracting foreign investment and thus the possibility of finding new investment projects and variety have an impact on the development of the Iraqi economy. At the same time, 33\% of the respondents say the opposite, believing they do not invest properly and therefore there will be no new projects.

As a result of the above analysis, the SME financial reporting standard is of great importance in improving the quality of accounting information and increasing the comparability of the financial statements of small and medium-sized companies at the international level, which also helps to facilitate the understanding of the financial statements When read by a foreign investor if the standard is adopted effectively.

Accordingly, the hypothesis that the adoption of the International Financial Reporting Standard (IFRS) for small and medium-sized enterprises (SMEs) may attract foreign investment is accepted.

\section{Conclusions and Recommendations}

\subsection{Conclusions}

1) Small and medium-sized enterprises (SMEs) represent the backbone of the private sector throughout the world and play an important role in the global economy if they account for about $95 \%$ of all companies around the world and contribute to the process of economic growth at various stages as they do not only contribute to raising production significantly, but also achieve social goals and contribute to attracting foreign exchange reserves as well as contribute to job creatio.

2) Foreign investment is a type of investment that has aroused controversy and interest, because of the multiplicity of its sources, forms and effects in its host countries. It involves the export of capital from a particular country called the exporting country to another country that is called the importing or host country, as investment is made in specific projects and sectors. Foreign investment is classified into two main areas: direct and indirect investments.

3) The main objective of the international financial reporting standard is to develop principles and baselines that are simplified and appropriate to the needs of such companies, since the absence of such a standard makes small and medium-sized enterprises resort to full international standards, which is a burden to them on the one hand. The cost of commitment consists of 35 parts; each part cares about a particular subject in terms of recognition, measurement and disclosure.

4) The common accounting system applied in small and medium-sized enterprises (SMEs) has been criticized for its obsolescence, although it was amended in 2011, but does not conform to the requirements of international standard.

5) The fundamentals of the transition to the international financial reporting standard in the Iraqi environment remain incomplete in terms of the appropriate political environment and the legal and legislative environment that initiate this 
transformation as well as the economic and regulatory environment.

6) A number of positive implications for the development of the Iraqi economy have been identified as a result of the shift towards international accounting standards, if the transformation process is planned and considered. One of the most important of these is the creation of a fertile and attractive environment for investment, access to sources of finance, increased revenues of the banking sector in the domestic product, and the entry of the Iraqi economy into the international economy.

\subsection{Recommendations}

1) Despite the potential positive repercussions of small and medium-sized enterprises (SMEs) in the Iraqi environment as a result of the shift towards the international financial reporting standard, this does not mean that the transformation process is not accompanied by negative repercussions. It is therefore necessary to take steps to make a scientific, deliberate and planned transformation in order to reap the benefits of this transformation and avoid the drawbacks that may occur.

2) The need to undertake radical reforms at various political, legal, economic and regulatory levels with a view to creating the appropriate environment required by the process of transition towards the international Financial reporting standard for small and medium-sized enterprises.

3) The professional and regulatory bodies of the accountancy and auditing profession in Iraq (the Financial Supervisory Board, the Association of Accountants and Auditors, the Board of Accounting and supervisory standards, the auditing and Audit Profession Council) should exercise its real role and be the leader in the transformation process.

4) The need for educational programmers, mainly supported by the State as well as professional, financial, banking and civil society organizations, to include seminars, conferences, workshops and forums at various levels with a view to publicizing the international Financial reporting standard for small and medium-sized enterprises and its importance And how to transform it in the right way that ensures positive benefits from it.

\section{Conflicts of Interest}

The authors declare no conflicts of interest regarding the publication of this paper.

\section{References}

[1] Mirza, A.A. and Hall, G.J. (2011) Manual and Book of Practical Implementation of International Financial Reporting Standards. 3rd Edition, Translation of the Arab Society of Accountants Jordan. Printed in the Hashemite Kingdom of Jordan-Amman, 551.

[2] Jazer, H.A.-T. and Ruwaiha, H.A. (2014) The Impact of the International Standard on Small and Medium Enterprises on the Determination of the Tax Base in Egyp- 
tian Companies (Analytical Study). Presented to the Fifth Annual Conference of Accounting Department, Faculty of Commerce, Cairo University, Egypt, 8.

[3] Tamimi, A.H. and Halim, S.Q. (2015) Adaptation of International Accounting Standards for Small and Medium-sized Enterprises and Their Applicability to the Local Environment. Journal of Al-Rafidain College, No. 36, 5.

[4] Al-Khuzaie, R.A.H.H. (2008) The Role of Credit Policy and Credit Procedures in Microfinance Financing (Applied Study in a Sample of Iraqi Commercial Banks). Higher Diploma Research for Master in Financial and Accounting Techniques, Technical College of Management, Baghdad, 32.

[5] Ensari, M.Ş. and Karabay, M.E. (2014) What Helps to Make SMEs Successful in Global Markets. 10th International Strategic Management Conference, Procedia-Social and Behavioral Sciences, Istanbul, 2014, 192-201. http://www.sciencedirect.com

[6] Al-Asrj, H.A. (2010) Small and Medium Enterprises and Their Role in Employment in the Arab Countries. Research Presented in Al-Ba'ath Magazine, Egypt, 16-17.

[7] Kumar, K.A. (2014) International Financial Reporting Standard (IFRS): Prospects and Challenges. Journal of Accounting \& marketing, 3, 2.

[8] http://www.ifrs.org

[9] Pacter, P. (2017) Pocket Guide to IFRS Standards. The Global Financial Reporting Language IFRS Foundation, 10.

[10] Azzawi, O. and Amal, M. (2012) International Financial Reporting Standard for Small and Medium Enterprises: An Opportunity and a Challenge for Developing Countries. Study at the University of Qasidi Marbah Ouargla, Faculty of Economic, Commercial and Management Sciences, Algeria, 97.

[11] Pascu, A.-M. and Vasiliu, A. (2011) CES Working Papers, III, (1) International Financial Reporting Standard for Small and Medium-Sized Entities-A New Challenge for the European Union. 124.

http://www.ceswp.uaic.ro/articles/CESWP2011_III1_PAS.pdf

[12] Amier, S. and Farooq, U. (2010) Assessing the Preparedness of Small and Medium-sized Entities in Sweden to Adopt International Financial Reporting Standard (IFRS) for Small and Medium-sized Entities (SMEs). Master Thesis, Umeå School of Business, Umeå University, Umeå, 28.

[13] Yunus, Z. and Fawzi, A. (2017) The Advantages of Implementing International Accounting Standards in Small and Medium Enterprises. A Study Presented to the $\mathrm{Na}$ tional Forum on the Sustainability of Small and Medium Enterprises, Faculty of Economic and Commercial Sciences and Science, Al-Shaheed University, Algeria, 7.

[14] Judges, M.M.A. (2012) Impediments to the Application of the International Financial Reporting Standard for Small and Medium-Sized Enterprises in Jordan from Jordanian Auditors' Perspective. Master Thesis, Faculty of Economics and Administrative Sciences, Yarmouk University, Irbid, 48.

[15] Siam, W.Z. (2009) The Possibility of Implementing International Financial Reporting Standards for SMEs in the Jordanian Environment. Presented to the First International Scientific Conference (Challenges of Globalization of Financial Systems), Faculty of Economics and Administrative Sciences, Hashemite University, Zarqa, 96.

[16] Micah, L.T. (2005) The Future of Foreign Investment in Iraq in the Light of Contemporary Arab Experiences. Unpublished Master Thesis, Faculty of Management and Economics, Mustansiriya University, Baghdad, 5. 
[17] Al Shammari, H.M.H. (2015) Tax Incentives and Their Importance in Attracting Foreign Direct Investment. Research Submitted for the High Diploma in Taxes, the Higher Institute of Accounting and Financial Studies, University of Baghdad, Baghdad, 32.

[18] Iraqi Investment Law 13 of 2006 and Its Amendments. 4.

[19] Saad, G.A. (2008) Foreign Investment and Its Impact on Accounting Applications in Iraq. Study in a Sample of Iraqi Banks, Special Contribution, Master Thesis, Faculty of Management and Economics, Mustansiriya University, Baghdad, 13-25.

[20] Majid, M.H. (2016) The Role of the Stock Market in Attracting Foreign Direct Investment to the Banking Sector (Applied Research in the Iraqi Market for Securities). Research Submitted to Obtain a Higher Diploma in Banks Unpublished, the Higher Institute of Accounting and Finance, Baghdad, 36-38.

[21] Mahdi, M.F. (2014) The Impact of Foreign Direct Investment in Some Indicators of the Iraqi Stock Exchange (Analytical Study for the Period 2007-2013). Master Thesis, Faculty of Management and Economics, Mustansiriya University, Baghdad, 23-28.

[22] Afloki, R.H. (2016) The Role of Monetary Policy in Attracting Foreign Direct Investment to Selected Countries with a Special Reference to the Kurdistan Region of Iraq. Doctoral Thesis, Faculty of Management and Economics, University of Baghdad, Baghdad, 41-42. 